\title{
$100 \mathrm{~kg} / \mathrm{mm}^{2}$ 級高張力鋼溶接熱影響部について
}

\author{
中村 素* 栗山良員 ${ }^{*}$ 山崎康久*
}

Hajime Nakamura, Yoshikazu Kuriyama and Yasuhisa Yamazaki : A Study on the Weld-Heat-Affected Zone of $100 \mathrm{~kg} / \mathrm{mm}^{2}$ Grade High Strength Steel. In the preceding paper, the authors reported that a remarkable brittle zone exists in HAZ (Heat-Affected-Zone) of HT-100 steel welded joints. The results of brittle fracture tests showed that brittle cracks always run over the parts of 0.5 to $1.0 \mathrm{~mm}$ apart from the fusion line heated to $1150^{\circ} \sim 1350^{\circ} \mathrm{C}$ during welding. Therefore it is important to make clear why HAZ of HT-100 steel shows such a brittle behavior.

Chemical analysis showed that no remarkable changes in composition were observed across HAZ, and this was also confirmed by an X-ray-microanalyser. The increase of free nitrogen as a result of decomposition of AlN in the steel was though to be not harmful to the embrittlement of HAZ. After various investigations the authors concluded that the embrittlement of HAZ was mainly dependent on the microstructure change due to heating above $\mathrm{Ac}_{3}$ and rapid cooling during welding.

(Received March 31, 1967)

\section{I. 緒 言}

HT-100 鋼の溶接熱影響部とくに融合部に脆化領域が存 在し，溶接欠陥が共存した場合低応力破壊する可能性のあ ることが各種の大型，小型脆性破壊試験で明らかにされた ことを前報で報告した，溶接熱影響部の脆化は溶接時にう ける熱履歴に密接な関係があることは明白で,どのような 熱履歷をうけるかを追求する必要がある。融合線からの距 離がはなれるにしたがつて到達する最高加熱温度は低下す るが, 融合線からの距離と最高加熱温度との関係は古く

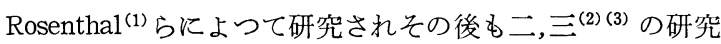
者によつて解明されている，調質型高張力鋼に扣よぼす溶 接熱サイクルの影響に関しては，鈴木，田村 ${ }^{(4)}$ 㧊よび西， 鈴木，下山占)らの研究がある。いずれも溶接熱影響部に相 当する熱サイクル怙よび応力サイクルを試験片に再現し, 最高加熱温度，冷却速度などの影響を明らかにしている。

前報で述べたごとく，供試 HT-100 鋼溶接熱影響部で脆 性亀裂が伝播する領域はつねに融合部から $0.5 \sim 1.0 \mathrm{~mm}$ 母材よりの部分であつた。 HT-100 鋼溶接部の脆化現象対 策を確立するには，その機構を明確にする必要があるので この報告に打いては熱サイクルを計算㐨よび実験で確認し た上，化学分析拉よびX線マイクロアナライザにより成分 変動を検討しさらに光学, 電子顕微鏡で組織および微小析 出物を解明した。これらの実験を経てから，再現溶接熱サ イクル装置により脆化部を再現し脆化機構を明らかにし た.

* 石川島播磨重工業株式会社 (Ishikawajima-Harima Heavy Industries Co., Ltd., Tokyo)

(1) D.Rosenthal: Weld. J., $20(1940), 220 \mathrm{~s}$.

(2) W.F. Hess, L. L. Merril, E.F. Nippes and A.P. Bunk: Weld. J., 22 (1942), $377 \mathrm{~s}$.

(3) C.Adams: Weld.J., 37 (1958), $210 \mathrm{~s}$.

（4）鈴木, 田村：金属材料技術研究所報告, 4 (1961), No.3, 47.

（5）西，鈴木，下山：三菱重工技報，1(1964)，1.

(6) H.F. Beeghly: Anal.Chem., 21 (1944), 12.

\section{II. 実 験 方 法}

\section{1. 溶接熱影響部の熱サイクル測定}

予熱 $120^{\circ} \mathrm{C}$, 入熱 32000 joule $/ \mathrm{cm}$ で溶接し熱影響部の温 度測定を行なつた。試験板の寸法扔よび溶接順序を Fig.1 に示す。
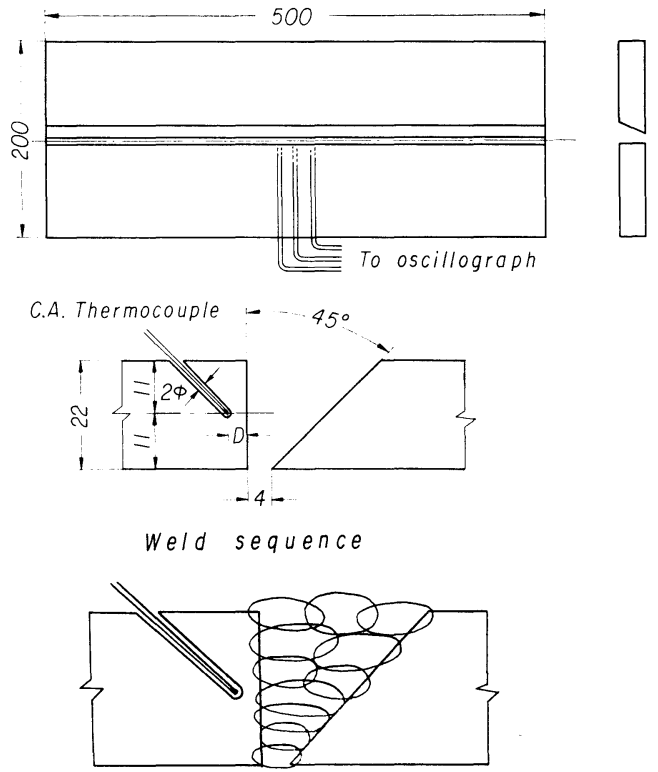

Fig.1 Specimen for temperature measuring.

\section{2. 化学成分の定量分析}

溶接金属を融合線まで機械加工で除去したのち, 径 2 $\mathrm{mm}$ のドリルを用いて熱影響部に深さ 0 ～ $2 \mathrm{~mm}$ 抢よび 2 $4 \mathrm{~mm}$ の孔を加工し，それぞれの部分から化学分析試料を 採取し, C, Si, Mn, P, S, Ni, Cr, Mo のほか酸可溶の Al 特 よび $\mathrm{Al}_{2} \mathrm{O}_{3}, \mathrm{~N}$ (total N) ならびに AlN の定量分析を行なつ た. AlNの分析は Beeghly 法 ${ }^{(6)}$ とより試料をハロゲンエス テル中に溶かし残渣中の $\mathrm{N}$ Kjeldahl 法で定量し，このN 
に当量の $\mathrm{Al}$ を計算で求め $\mathrm{AlN}$ 量とした，A1N 以外に窒化 物をつくる $\mathrm{Si}, \mathrm{Fe}, \mathrm{Cr}$ 扤よび $\mathrm{Mn}$ が共存する鋼では，八口 ゲンエステル溶解による残渣中の $\mathrm{N}$ はかならずしも AlN としてのNのみではないが, 分離できないのですべて AlN とした。 total N は同じくKjeldahl 法で定量した。このほ か, 融合部付近の化学成分变化を詳細かつ連続的にしらべ るためX線マイクロアナライザ†を用いて $\mathrm{Cr}, \mathrm{Ni}$ 扣よび Mo を定量した，加速電圧は $25 \mathrm{kV}$ ，試料の移動速度を 100 $\mu / \mathrm{min}$ と，溶接金属から融合線を経て母材溶接熱影響部 までの間 $6 \mathrm{~mm}$ に X 線分光計を走查させた。定量位置は

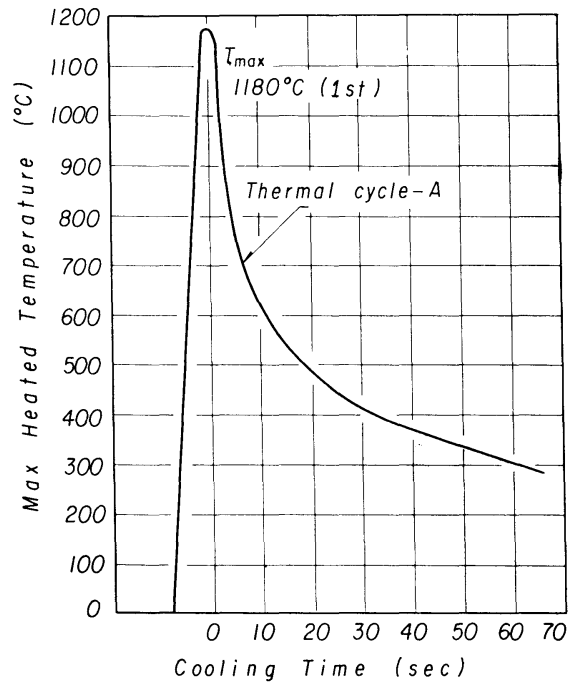

Fig.2-1 Thermal cycle-A.

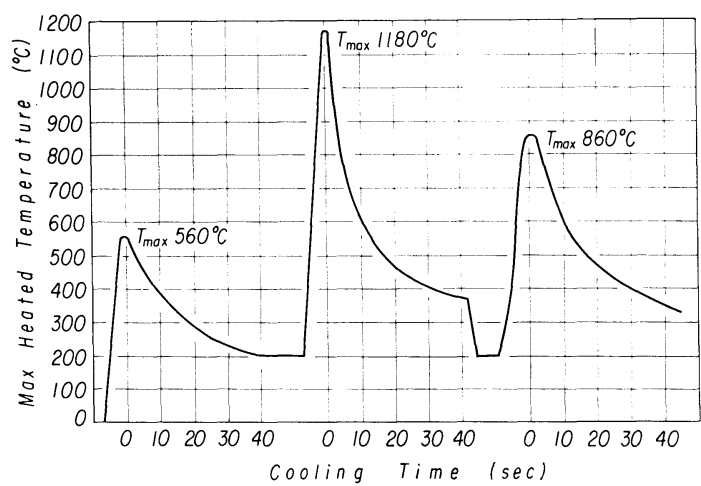

Fig.2-2 Thermal cycle-B.

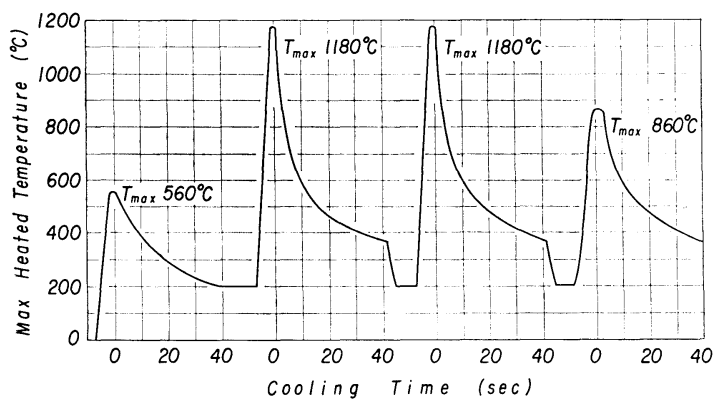

Fig.2-3 Thermal cycle-C.
$200 \mu$ ごととし，X線の照射面積はほぼ 6 ～ $8 \mu$ で連続照射 を行なつた。

\section{3. 顕 微 鏡 組 織}

溶接部を $3 \%$ Nital で腐食し 組織を検鏡し，かつカーボ ン抽出レプリカ法を用い電子顕微鏡で組織を観察した上, 微小析出物を電子線回折により検討した.

\section{4. 溶接熱サイクル再現試験片に よる V シャルピー試験}

融合線より $0.5 \sim 1.0 \mathrm{~mm}$ 母材よりの部分が5ける熱サ イクルを試験片に再現し，Vシャルピー試験を行なつた。 高周波誘導加熱方式の熱サイクル再現装置を用い，加熱制 御用として径が $0.3 \mathrm{~mm}$ のアルメルークロメル熱電対を試 験片中央に溶接した．Fig.2 亿使用した溶接熱サイクル曲 線を示す。

\section{III. 実 験 結 果}

\section{1. 溶接熱影響部の温度-時間曲線 測 定 結 果}

融合線からの距離を 1,2 および $3 \mathrm{~mm}$ と変えて溶接熱影 響部の温度-時間曲線を求めた結果を Fig. 3 亿示す. 距離

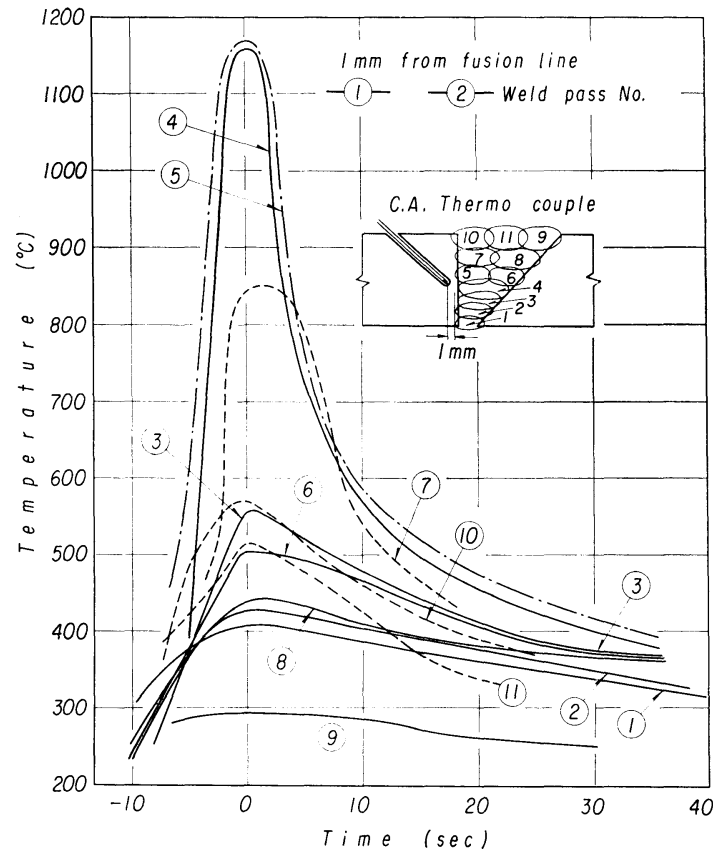

Fig.3 Temp-time curves for H.A.Z. ( $1 \mathrm{~mm}$ from fusion line).

が $1 \mathrm{~mm}$ の点では隣接するビードが通過するとき，最高 $1180^{\circ} \mathrm{C}$ に加熱され，隣接する前後のビードにより $560^{\circ} \sim$ $860^{\circ} \mathrm{C}$ に加熱される。距離が $2 \mathrm{~mm}$ 打よび $4 \mathrm{~mm}$ では，そ れぞれの最高加熱温度が $950^{\circ}$ 牤よび $700^{\circ} \mathrm{C}$ になることが わかる。融合線から 0.5〜1 $\mathrm{mm}$ に認められる脆化部は, 入熱が 32000 joule/cm のとき，ほぼ Fig.3 の (5) 曲線のご とき熱サイクルをうけることがわかる。すすなわち最高加熱

$\dagger$ 日本電子工業 KK 製, 型式 JXA-3-367. 
温度はほぼ $1180^{\circ} \mathrm{C} て ゙, 590^{\circ} \mathrm{C}$ までは約 $60^{\circ} \mathrm{C} / \mathrm{sec} て ゙$ 泠却す る熱サイクルである.

溶接熱影響部がうける熱サイクルは, Rosenthal ${ }^{(1)}$ が解 明し，温度分布拉よび冷却速度に関し理論式を報告してい る. その後この理論式を中心に，アーク溶接の諸因子がと り入れられた種々の式が誘導されている。なかでも熱源が ある大ささをもち, 最高温度を母材の融点とする Adams ${ }^{(3)}$ の誘導した次式が実際の計測結果とよく一致するといわれ ている.

$$
\begin{array}{rlrl}
\frac{1}{T_{p}-T_{0}} & =\frac{V r^{\prime} \operatorname{te} C_{p} \sqrt{2 \pi e}}{Q} & \frac{1}{T_{m}-T_{0}} \\
\text { ただし, } & T_{p}=\text { 最高温度 }\left({ }^{\circ} \mathrm{C}\right) & T_{m}=\text { 母材の融点 }\left({ }^{\circ} \mathrm{C}\right) \\
T_{0} & =\text { 母材の初温 }\left({ }^{\circ} \mathrm{C}\right) & \\
V & =\text { アークの移動速度 }(\mathrm{cm} / \mathrm{sec}) \\
r^{\prime} & =\text { 融合線か らの距離 }(\mathrm{cm}) \\
t & =\text { 板厚 }(\mathrm{cm}) & C_{p}=\text { 比熱 }\left(\mathrm{cal} / \mathrm{g} \cdot{ }^{\circ} \mathrm{C}\right) \\
\rho & =\text { 密度 }\left(\mathrm{g} / \mathrm{cm}^{3}\right) & Q=\text { 実効入熱 }(\mathrm{cal} / \mathrm{sec})
\end{array}
$$

溶接条件は, $T_{0}=120, V=0.094 \mathrm{~cm} / \mathrm{sec}, t=2.2 \mathrm{~cm}$ で, 入熱は 32000 joule $/ \mathrm{cm}$ であり, 突合わせ溶接時の入熱実効 率を $0.75^{(1)}$ とすると $Q=536 \mathrm{cal} / \mathrm{sec}$ である. $800^{\circ} \sim 1000^{\circ} \mathrm{C}$ に招いて $C_{p}=0.21 \mathrm{cal} / \mathrm{g} \cdot{ }^{\circ} \mathrm{C}, \rho=7.8 \mathrm{~g} / \mathrm{cm}^{3}, T_{m}=1530^{\circ} \mathrm{C}$ を代入して $r^{\prime}=0.1,0.2,0.3,0.4,0.5$ およ゙ $1 \mathrm{~cm}$ の点にお ける $T_{p}$ を求め実測結果と比較すると Table 1 のごとくで

Table 1 Maximum heated temperature of H.A.Z calculated value and observed value.

\begin{tabular}{c|c|c}
\hline $\begin{array}{c}\text { Distance from } \\
\text { fused line }(\mathrm{cm})\end{array}$ & $\begin{array}{c}\text { Calculated value } \\
\left({ }^{\circ} \mathrm{C}\right)\end{array}$ & $\begin{array}{c}\text { Observed value } \\
\left({ }^{\circ} \mathrm{C}\right)\end{array}$ \\
\hline 0.05 & 1308 & - \\
0.10 & 1122 & $1 \overline{78}$ \\
0.20 & 920 & 900 \\
0.30 & 778 & $\overline{640}$ \\
0.40 & 680 & $\bar{\vdots}$ \\
0.50 & 604 & - \\
$\vdots$ & $\vdots$ & \\
1.00 & 417 & \\
\hline
\end{tabular}

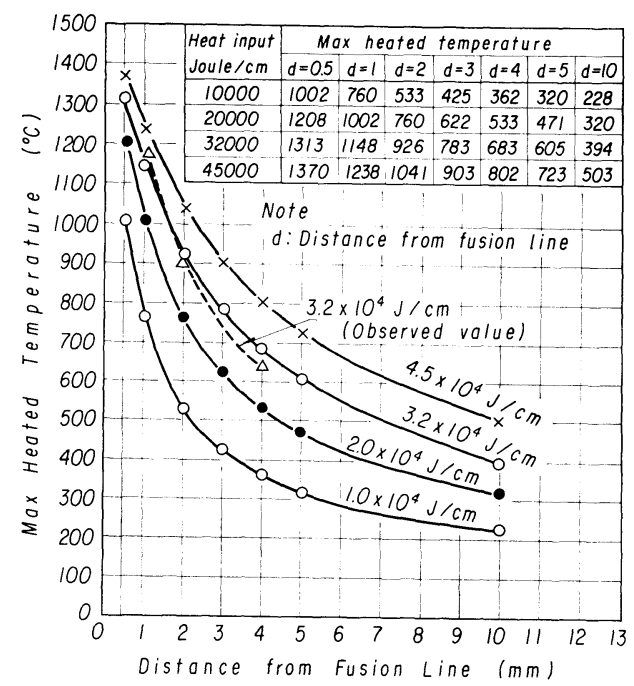

Fig. 4 Relationship between maximum temperature and heat-input.

$0.10 \%$ の $\mathrm{Al}$ が添加され，圧延拈よび熱処理過程で適量の AlN となり，機械的性質の向上に寄与している。溶接熱に より加熱されると A1N は分解し, A1N の効果が消失し, かつ固溶 $\mathrm{N} か ゙$ 增加するので母材原質部より脆化することが 予想される．また融合部付近は溶着金属と母材とが混合し 中間合金が生じ，その成分いかんではもろい金属となるこ ともあり得る。溶接熱影響部について化学成分の定量分析 を行なつた結果を Table 2 に示す。成分中 C, Si, P, S, Cr， Mo 扎よび V は母材原質部と差は認められなかつた。しか

\begin{tabular}{|c|c|c|c|c|c|c|c|c|c|c|c|c|c|c|}
\hline \multirow{2}{*}{$\begin{array}{l}\text { Distance from } \\
\text { Fusion line }(\mathrm{cm})\end{array}$} & \multicolumn{14}{|c|}{ Chemical compositions $(\%)$} \\
\hline & $\mathrm{C}$ & $\mathrm{Si}$ & $\mathrm{Mn}$ & $\mathrm{P}$ & S & $\mathrm{Cr}$ & $\mathrm{Ni}$ & Mo & V & $\mathrm{AlN}$ & T.N. & Free $\mathrm{N}$ & Sol.A1 & $\mathrm{A} 10$ \\
\hline $0 \sim 0.2$ & 0.14 & 0.31 & 0.99 & 0.007 & 0.003 & 0.55 & 1.37 & 0.43 & 0.05 & 0.031 & 0.018 & 0.0074 & 0.083 & 0.012 \\
\hline $0.2 \sim 0.4$ & 0.15 & 0.28 & 0.88 & 0.007 & 0.003 & 0.55 & 1.21 & 0.45 & 0.06 & 0.047 & 0.022 & 0.0060 & 0.069 & 0.015 \\
\hline Base metal & 0.15 & 0.29 & 0.85 & 0.014 & 0.007 & 0.59 & 1.20 & 0.55 & 0.06 & 0.044 & 0.019 & 0.0040 & 0.069 & 0.014 \\
\hline
\end{tabular}
し $\mathrm{Ni}$ 量は融合線から $2 \mathrm{~mm}$ 以内の領域で母材よりる $0.16 \%$ 高い $1.37 \%$ を示した。 これは溶着金属の $\mathrm{Ni}$ がほ ぼ $2.7 \%$ で材よりも高く融合部付近が混合によつて Ni 量が増加したものと考兄られる，Mn量についても同様の ことがいえる。融合線から $2 \mathrm{~mm}$ 以内の AlN 量は母材よ

Table 2 Chemical compositions of H.A.Z. of HT 100 steel.

Note: T.N-Total nitrogen

Sol.Al-Soluble alminum

ほぼ一致している，溶接入熱を 10000,20000 および 45000 joule $/ \mathrm{cm}$ と変えたときと融合線からの 距離と最高温度と の関係を Adams の式で求め Fig.4 に示した. 入熱の増大 につれて, ある点に拈ける最高温度が上昇し, 融合線から 0.5 1.0 mm の領域は溶接入熱が実用範囲の 20000 32000 joule $/ \mathrm{cm}$ であれば $1000^{\circ} \sim 1350^{\circ} \mathrm{C}$ に加熱されることがわ かる。

\section{2. 化学成 分}

供試 HT-100 鋼は製鋼過程で約 $0.015 \%$ の $\mathrm{N}$ と 0.08
りも $0.013 \%, \mathrm{Al}_{2} \mathrm{O}_{3}$ は $0.012 \%$ 低く, 酸可溶の $\mathrm{Al}$ は $0.14 \%$ 増加している. 融合線から 2 4 mm の領域ではこ のような変化はみとめられず母材原質部とほぼ同等であつ た. したがつて，溶接熱によつて $900^{\circ} \mathrm{C}$ 以上に加熱された と考党られる融合線から $2 \mathrm{~mm}$ 以内の領域では AlN が分 解している事実が確認された，著者の一人がさきに行なつ た研究(7) によれば $\mathrm{AlN}$ は $1100^{\circ} \mathrm{C}$ 以上に加熱されると $\mathrm{Al}$ と $\mathrm{N}$ に分離して固溶を開始し， $1350^{\circ} \mathrm{C}$ 以上でほぽ完全に

（7）中村, 深川：材料科学, 1 (1964), No.5, 273. 
matrix 中に圆溶するが，その溶解度は成分，前処理によ つて異なり，酸可溶の $\mathrm{A} 1$ ，固溶 Nが多くなるほど溶解度 曲線は高温側に移行する。溶接熱影響部比いては加熱速 度が速いので $1400^{\circ} \mathrm{C}$ 付近に加熱された融合部近傍にも未 固溶の AIN が電顕で観察 ${ }^{(8)}$ されている。

0.066\% AiN を含有する低栵素鋼を，溶接熱サイクル再 現装置を用いて $800^{\circ} \sim 1300^{\circ} \mathrm{C}$ に急速加熱，冷却し AlN の 変化をしらべた結果はFig.5に示すと频りで, $1200^{\circ} \mathrm{C} に$

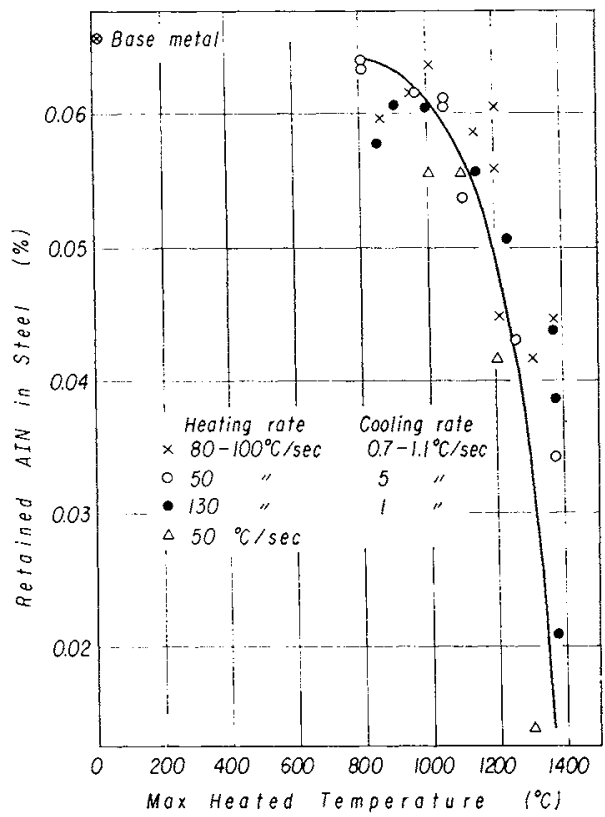

Fig. 5 Relationship between maximum heated temperature and retained AIN.

加熱されると約 $25 \%$ の A1N が分解することが判明した。 今回の年駼では， $900^{\circ} \mathrm{C}$ 以上に加熱された領域の A1N 量 は $0.031 \%$ て度材原質部の $0.044 \%$ にくらべ $34 \%$ 分解し たことになる. Fig. 5 の AIN 溶解度曲線によると $34 \%$ AIN

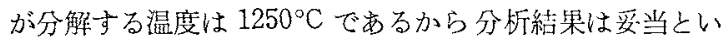
光よ5。結局，脆化領域は溶接熱影響に上り A1Nが 30 40\% 分解し，固溶 Nが 0.003〜0.004\% 增大することが明 らかになつた。

X線マイクロアナライザを用いて溶接部の $\mathrm{Cr}, \mathrm{Ni}$ 星の 変動をしらべた絬果は Table 3 の之招りで, $\mathrm{Cr}, \mathrm{Ni}$ の偏 析にとるなら若干のばらつきは浔めら机るが，大きな変動

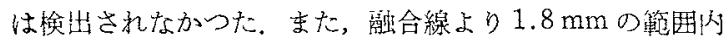
飞特ける $\mathrm{Ni}$ 量の平均俻は $0.796 \%$ で, $2.2 \sim 3.6 \mathrm{~mm}$ の範 井队の Ni 平均量は $0.877 \%$ で㫫り，化学分析の際检出さ 机た溶着金属との沘合による $\mathrm{Ni}$ 荲の增加は染好られなか つた。こ机は混合による $\mathrm{Ni}$ 量の增加が，融合線のみに集 中し，溶融しなかつた溶接熱影響部には生じなかつたため と解积される。

\section{3. 顕微鏡 組 織}

（8）長谷部：溶接学会梳，33(1964)，No.12，p.14.
Table $3 \mathrm{Cr}$, Ni contents in H.A.Z. analyzed by $\mathrm{X}$-ray micro-analyzer.

\begin{tabular}{c|cc}
\hline $\begin{array}{l}\text { Location of } \\
\text { survey }(\mu)\end{array}$ & $\mathrm{Cr}(\%)$ & $\mathrm{Ni}(\%)$ \\
-200 & 0.656 & 1.660 \\
0 & 0.487 & 0.598 \\
200 & 0.511 & 0.770 \\
400 & 0.521 & 0.771 \\
600 & 0.434 & 0.964 \\
800 & 0.434 & 1.003 \\
1000 & 0.385 & 0.771 \\
1400 & 0.501 & 0.675 \\
1800 & 0.511 & 0.819 \\
2200 & 0.463 & 0.867 \\
2600 & 0.395 & 0.877 \\
2800 & 0.521 & 0.887 \\
3000 & 0.617 & 0.993 \\
3200 & 0.578 & 0.694 \\
3300 & 0.550 & 1.156 \\
3400 & 0.405 & 0.964 \\
3600 & 0.443 & 0.568 \\
Base metal & 0.54 & 0.93 \\
\hline
\end{tabular}

入熱 32000 joule/cm で溶接した供試 HT-100 鋼溶接部 の光学晋徽鏡組織（倍率 100 倍) Photo. 1 K示す。融合 線加ら $0.5 \mathrm{~mm}$ の点は $1350^{\circ} \mathrm{C}$ に加熱され急冷されるので， ヘーーナイトとマルテンサイトの潉合組織を示し，350〜380 Hv の硬さを示す領域である。融合線から $2 \sim 3 \mathrm{~mm}$ 離れた 部分は $\mathrm{Ac}_{1}$ 点 $\left(730^{\circ} \mathrm{C}\right)$ 以上 $9790^{\circ} \sim 900^{\circ} \mathrm{C}$ に加熱されてい るので炭化物が粒界に凝集しフェライト粒るややまる久を 帯びているが，相材と同㥞点密な組織が保心れている。

将材和よび溶接熱影響部のカ一ボン抽出レプリカによる 電顕写真をPhoto. 2 示す。材中他は長さ $6 \sim 7 \mu$ の矩 形析出物之内形の析出物が見ら机るが，これは Photo.3 で示すごとく $\mathrm{AlN}$ 拉よび $\mathrm{Cr}_{23} \mathrm{C}_{6}$ と判断される。溶接熱影 響部には舟材と異なつて析出物があ亦り存在しないが， A1N と考光られる析出物が若干恋められた。冷却速度の点 からこの AlN は一度固溶したものが再析出したものでは なく，未固溶の AIN である。

\section{4. 熱サイクルを再現した試験材

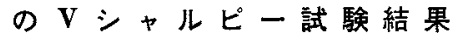

HT-100 鍓溶接熱影響部の脆化領域は融合線より 0.5 〜 $1.0 \mathrm{~mm}$ 母材よりの部分で，この部分が 受けた熱サイクル を試験材にかけ、Vシャルピー試験を行なつた結果を Fig.

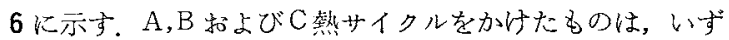
れる枉林よりるいちじるしく脆化している。3種の熱サイ クルのなかでは(C) 熱サイクルをか惊たすのが若干高い破 面㟟移温度Trs を示している程度で，3者間比大き差は 梁められなかつた。衝慗值遷移曲線についても京㥞のこと がいえる。

同一チャージの HT-100 銅溶接部(溶接入等は 30000 joule $/ \mathrm{cm}$ ) の繦合部付近の层材部に划欠を加工した $2 \mathrm{mmV}$ シャルピー試験に括ける破面ならびに衝撃値遷移曲線は Fig.7 のごとくで Fig.6 の結棵と添济同様で，破面遷移温

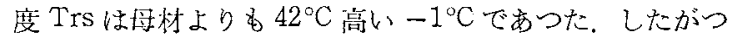
て，再現溶接熱サイタルをか付た試験片の衝慗性筫は溶接 


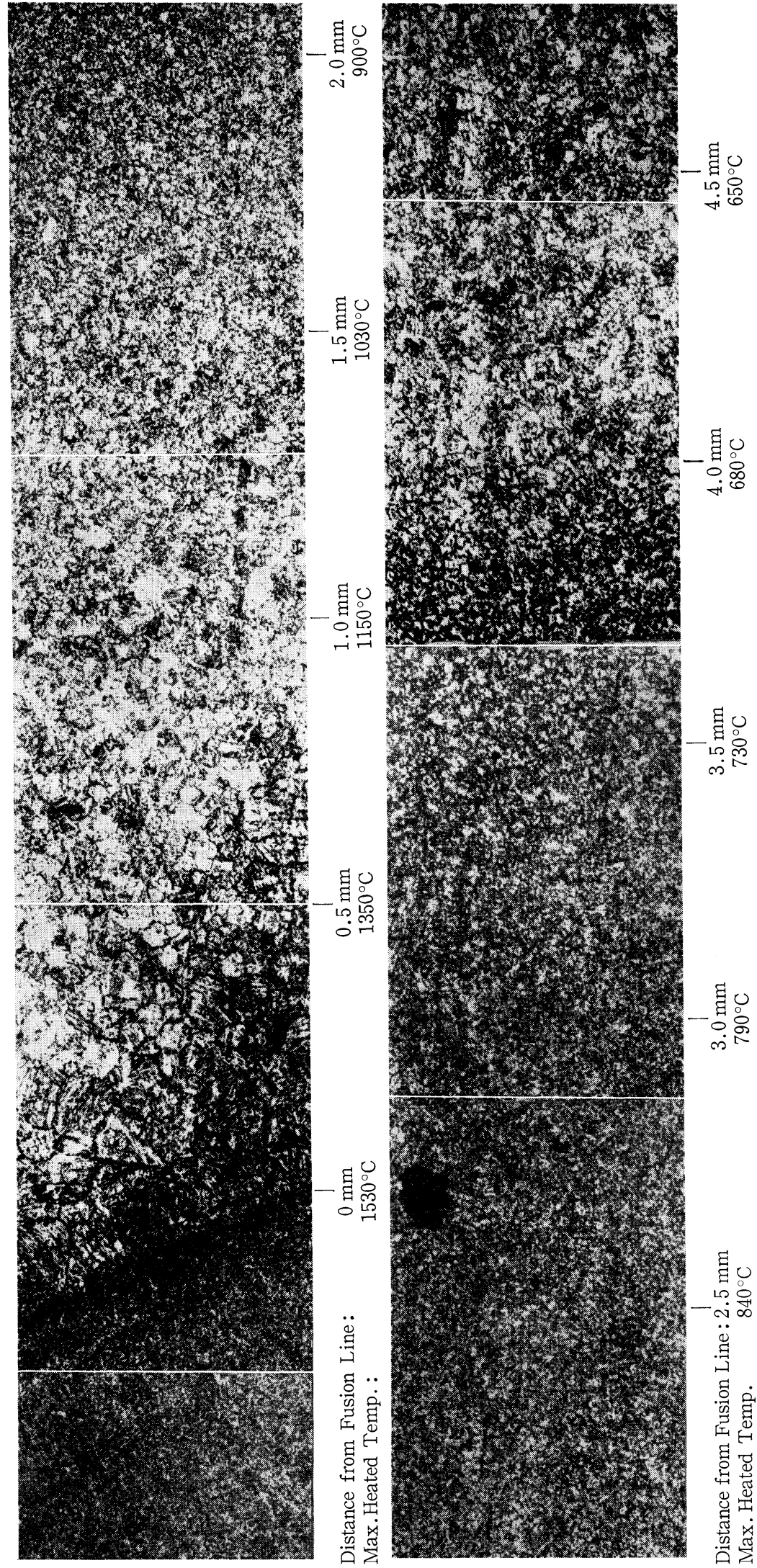

Photo.1 Microstructure of weld-heat-affected zone of HT-100 steel. $(\times 100 \times 4 / 5)$
熱影響部の融合部付近の性質を再 現していると見なすことができよ 5 .

曲線 (B) (C) のごとき多重熱サ イクルをかけたものと(A)のごと く最高加熱温度が $1180^{\circ} \mathrm{C}$ の熱サ イクルを1回かけたものとの間に 大きな差異がなかつた。これは， $1180^{\circ} \mathrm{C}$ の熱サイクルを弓けるこ とが供試 HT-100 鋼溶接熱影響部 の脆化現象に対して支配的因子で あると考えられる。

$$
\begin{gathered}
\text { IV. 考 察 お よび } \\
\text { 結 論 }
\end{gathered}
$$

温度計測による溶接熱影響部の 最高加熱温度と, Adamsの理論式 による計算值はよく一致したので 溶接熱影響部の各点に拈ける最高 加熱温度を推測することが可能と なつた，各種脆性破壊試験で脆性 亀裂が伝播した部分は，前報で述 ベたごとく融合線より $0.5 \sim 1.0$ $\mathrm{mm}$ 離れた領域である。現地溶接 で管理可能な下限値とされている 溶接入熱 32000 joule/cm で溶接し た場合，この脆化領域がさらされ る最高加熱温度は $1150^{\circ} \sim 1350^{\circ} \mathrm{C}$ で組織はマルテンサイトとベーナ イトの混合組織であつた。化学分 析および $\mathrm{X}$ 線マイクロアナライザ によると融合部付近のみに溶着金 属との混合による $\mathrm{Ni}$ 量の増大が 認められ，また添加 $\mathrm{A} 1 \mathrm{~N}$ の分解に よる固溶Nの増加も認められた。 $\mathrm{Ni}$ 量の増加は切欠靱性をむしろ 向上させ脆化の原因とはならず， 固溶Nの増加も0.003 0.004\%で Total N 量にして $0.007 \%$ である. 一般に鋼中の固溶 Nが増加すると 切欠勒性が低下するといわれてい るが, Sage ${ }^{(9)}$ によれば鋼中の固溶 $\mathrm{N}$ が $0.004 \%$ から $0.007 \%$ 増加し たことによる $2 \mathrm{mmVシャルピー}$ 試験に扣ける破面遷移温度 Trs の上昇はほほ $10^{\circ} \mathrm{C}$ である、HT-

(9) A. M. Sage and F. E. L. Copley: J.Iron Steel Inst., $196(1960), 422$. 
100 鋼溶接融合部の破面遷移温度 Trs は母材原質部にくら べてほぼ $40^{\circ} \mathrm{C}$ 上屍して招り, AlN 分解による固溶 $\mathrm{N}$ の増
大る融合部の脆化の直接原因ではないと判断される.

固溶 $\mathrm{N}$ 量, 顕微鏡組織と切欠勒性の関係を検討するため

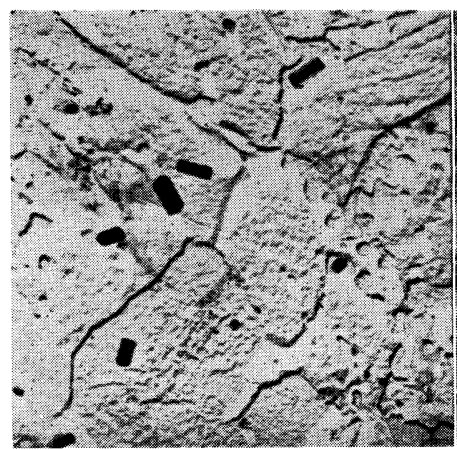

Base metal

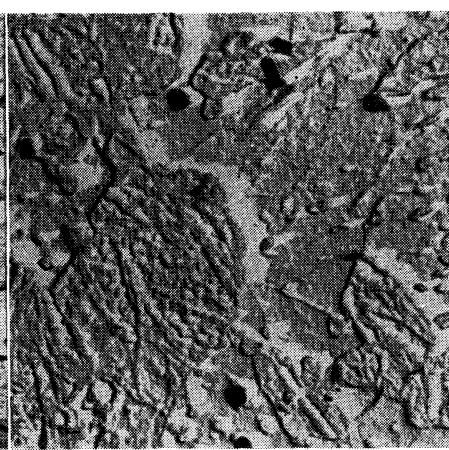

Weld-heat-affected zone

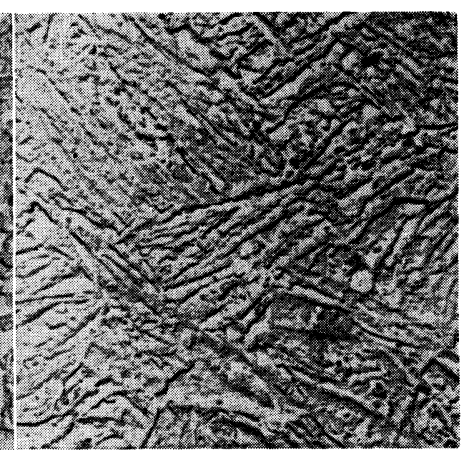

Weld metal

Photo.2 Microstructure of HT-100 steel weldment by electron microscope.

$(\times 5000)$

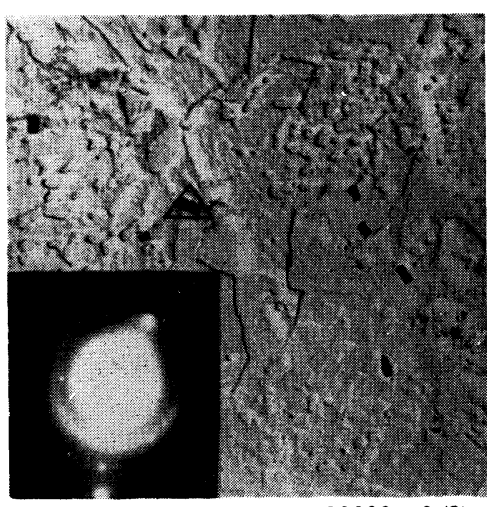

AlN $(\times 20000 \times 2 / 3)$

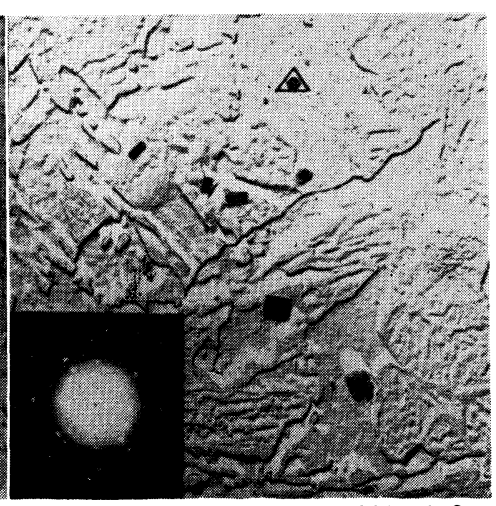

$\mathrm{Cr}_{23} \mathrm{C}_{6}(\times 20000 \times 2 / 3)$

Photo. 3 Electron diffraction patterns of HT-100 steel.

$\mathrm{HT}-100$ 鋼を $1000^{\circ}, 1150^{\circ}, 1250^{\circ}$ およ び $1350^{\circ} \mathrm{C}$ に加熱し，その後 $950^{\circ} \mathrm{C}$ ま で空泠し， $950^{\circ} \mathrm{C}$ で 10 分間保持して から室温まで空冷という熱処理を行な つた. かくのごとき熱処理によつてい ずれもマルテンサイトとベーナイトの 混合組織であるが粒度の異なつた組織 が得られた. 同時に鋼中の $\mathrm{AlN}$ 量も変 化し Table 4 の結果を得た。 これらの 熱処理を施した試験材につき $2 \mathrm{~mm} \mathrm{~V}$ シャルピー試験を行なつたところ, $1250^{\circ}$ および $1350^{\circ} \mathrm{C}$ 加熱材は Sage の 実験より予想される固溶 Nの増加にも とずく Trs の上年值よりもはるかに高い Trs $\left(70^{\circ} \mathrm{C}\right)$ を示 した。この事実より $1250^{\circ} \sim 1350^{\circ} \mathrm{C}$ に加熱冷却したときの HT-100 鋼の 脆化は固溶 N の増加のみによるものではな

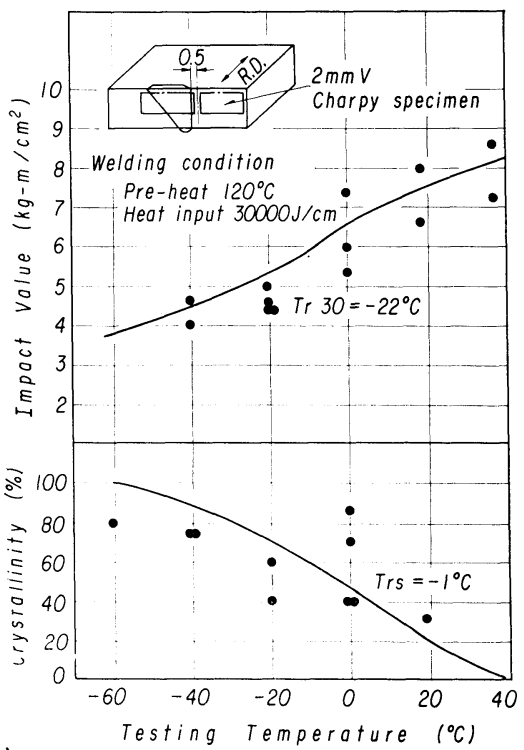

Fig.7 $2 \mathrm{mmV}$ charpy test results of specimens notched on fusion line.

Fig.6 Impact test results of various specimens duplicated synthetic weld thermal cycles. 
Table 4 Effects of heat treatment on retained AlN of HT-100 steel.

\begin{tabular}{|c|c|c|c|}
\hline Heat treatment & $\begin{array}{r}\mathrm{AlN} \\
(\%)\end{array}$ & $\int_{(\%)}^{\text {Total }} \mathrm{N}$ & $\begin{array}{c}\text { Free } \mathrm{N} \\
(\%)\end{array}$ \\
\hline $\begin{array}{r}1000^{\circ} \mathrm{C} \text { A.C. }-950^{\circ} \mathrm{C} \times 10 \mathrm{~min} \\
\text { A.C. }\end{array}$ & 0.043 & 0.020 & 0.0054 \\
\hline $\begin{array}{r}1150^{\circ} \mathrm{C} \mathrm{A} . \mathrm{C} .-950^{\circ} \mathrm{C} \times 10 \mathrm{~min} \\
\text { A.C. }\end{array}$ & 0.033 & 0.020 & 0.0088 \\
\hline $\begin{array}{r}1250^{\circ} \mathrm{C} \text { A.C. }-950^{\circ} \mathrm{C} \times 10 \mathrm{~min} \\
\text { A.C. }\end{array}$ & 0.008 & 0.020 & 0.0173 \\
\hline 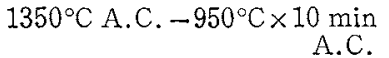 & 0.004 & 0.020 & 0.0187 \\
\hline Base metal & 0.004 & 0.019 & 0.0040 \\
\hline
\end{tabular}

く，加熱温度の相違による組織の相違が支配的因子である と考えられた。

融合線から医ば1 mm母材寄りの部分がうける溶接熱サ

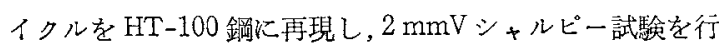
なつた。その結果，溶接継手の融合部に切欠を加工した 2
$\mathrm{mmV}$ ンャルピー試験による破面扣よび衝擊值遷䔟曲線と よく一致するい方じるしい脆化現象が認められた。

以上の実験結果より，HT-100 鋼溶接熱影響部の融合部 に検出された脆化現象は溶接熱サイクルによつてほぼ $1200^{\circ} \mathrm{C}$ 以上に加熱されることによつて生ずる組織変化が 主因で要ると判断された。この現象はHT-100鋼のみでは なく他の調質型高張力鈵にも共通である、溶融溶接を行な 弓限り溶接条件を変化させてもかかる温度に加熱される領 域が必ず存在するので，溶接構造物として使用するには脆 化領琙が存在して子継手性能を低下させない対策が必要で ある。

本研究にあたり媳切な指導を睤わつた東京工業大学中柇 教授に霍心より御礼申し上げ，実駼遂行にあたりご協力を いただいた石川島播磨重工業株式会社 構造研究室 前曰博 士に厚く御礼申し上げます。 